\title{
PEMBELAJARAN MENULIS KARANGAN EKSPOSISI MENGGUNAKAN MEDIA GAMBAR PESERTA DIDIK KELAS VIII SMPN 24 BANJARMASIN
}

\author{
IMPLEMENTATION OF EXPOSITION WRITING-LEARNING USING PICTURES \\ FOR STUDENTS KELASVIII SMPN 24 BANJARMASIN
}

\author{
Asha Cita Puteri Erdanu; Zulkifli Musaba; Rusma Noortyani \\ Program Studi Pendidikan Bahasa dan Sastra Indonesia \\ FKIP Universitas Lambung Mangkurat \\ ashaerdanu14@gmail.com
}

\begin{abstract}
Abstrak
Tujuan penelitian ini yakni memaparkan proses dari pelaksanaan pembelajaran me nulis karangan eksposisi dengan penggunaan media gambar pada kelas VIII peserta didik SMP Negeri 24 Banjarmasin. Metode penelitian yang di gunakan pada penelitian ini adalah deskriptif kualitatif. Data pada penelitian ini dianalisis dengan cara (1) mereduksi data; (2) menyajikan data; dan (3) memverifikasi data atau mengkonklusi. Penelitian ini menghasilkan pemaparan mengenai pelaksanaan penbelajaran menulis karangan eksposisi menggunakan media gambar yang terdiri dari 3 langkah kegiatan, di antaranya (1) pendahuluan, berisi salam dan doa, menyiapkan fisik dan psikis peserta didik, serta memberikan motivasi; (2) inti, yang terdiri dari kegiatan $5 \mathrm{M}$, yaitu mengamati, menanya, mengumpulkan informasi, menalar informasi dan mengomunikasikan hasil; serta (3) penutup.
\end{abstract}

Kata kunci: pelaksanaan pembelajaran, eksposisi, media gambar

\section{Abstract}

The purpose of researc is describe the procession of implementation of exposition writing learn using pictures media for students in Kelas VIII A SMP Negeri 24 Banjarmasin. The researc method used is descriptive qualitative. Datas were analyzed by (1) data reductiion; (2) data display; and (3) conclusion drawing or verification. The results of research indicate that the implementation of exposition writing learning using picture consists of three steps, which are (1) preliminary activities; (2) coreactivities, which consist of $5 M$ activities; and (3) closing activities.

Keywords: implementation of learning, exposition, pictures media

\section{Pendahuluan}

Pengajaran bahasa memiliki peran yang penting dalam proses mencerahkan kehidupan bangsa. Untuk merealisasikan upaya tersebut, proses pelaksanaan pembelajaran perlu diperhatikan. Pembelajaran bahasa Indonesia diajarkan kepada peserta didik agar mereka dapat terampil mempraktikkan bahasa Indonesia. Adapun pada penggunanaan bahasa
Indonesia, ada empat macam keterampilan dalam penggunaan berbahasa, yaitu menyimak, bicara, menbaca, serta menulis. Hal ini merujuk pada pendapat ahli yaitu Tarigan (2008) bahwa terdapat empat komponen keterampilan berbahasa, empat komponen itu dapat adalah keterampilan menyimak, keterampilan bicara, kterampilan membaca, dan keterampilan menulis. 
Menulis, menurut Tarigan (2008: 3) adalah suatu kegiatan dimana sifatnya produktif serta dapat diekspresikan. Maka dari itu, melalui aktivitas ini, seseorang dapat mengekspresikan diri dan perasaannya melalui sebuah hasil karya yang disebuttulisan. Dengan kata lain, dapat dimaknai bahwa menulis merupakan kererampilan berbahasa yang befungsi untuk menyampaikan pikiran menggunakan bahasa tulis.

Ada berbagai cara yang dapat ditempuh untuk mengasah keterampilan menulis peserta didik, di mana satu diantaranya adalah pembelajaran menulis karangan. Pembelajaran tersebut merujuk pada kurikulum dewasa ini, yakni kurikulum 2013 revisi 2017. Kurikulum tersebut memuat KompetensiInti 4 yaitu menncoba, membuat, dan menyajikan secara konkret (memakai, menguraikan, menyusun, mengubah, dan mengolah) serta secara abstrak (menulis, membaca, menghitung, menggambar, dan mengarang) mengacu pada materi yang telah dipelajarinya disekolah dan info lainnya di mana sumber tersebut selaras dengan konsep. Adapun Kompetensi Inti 4 tersebut merumuskan Kompetensi Dasar 4.6 sebagai berikut, yaitu memaparkan pendapat dan juga ide pokok dalam bentuk teks eksposisi atau artikel ilmiah populer (lingkungan hidup, kondisi sosial, dan atau keragaman budaya, dan lain-lain) secara lisan serta tulisan seraya mencermati struktur, unsur kebahasaan, serta aspek lisan.

Berdasarkan pemaparan tersebut di atas, peneliti tergugah untuk mengangkat masalah tentang pelaksanaan pembelajaran menulis karangan eksposisi menggunakan media gambar. Alat atau media yang dipilih adalah media gambar, karena dapat memudahkan peserta didiik dalam memaparkan info yang terdapat pada masalah atau tema yang dipilih. Dengan demikian, hubungan antara komponen pada masalah atau tema yang dipilih dapat dilihat dengan jelas.

Adapun sekolah yang penulis pilih sebagai tempat penelitian adalah sekolah menengah pertama yaitu SMP Negeri 24 Banjarmasin. Alasan penulis memilih untuk meneliti di sekolah tersebut karena SMP Negeri 24 Banjarmasin adalah sekolah yang mengaplikasikan kurikulum 2013 dan dilengkapi dengan para pendidik yang terlatih. Selain itu, sekolah tersebut berada di pusat kota dan banyak diminati oleh peserta didik di daerah Banjarmasin.

Mengacu pada latar belakang yang dipaparkan tersebut di atas, tujuan peneitian ini yaitu mendeskripsikan langkah-langkah pelaksanaan pembelajaran menulis karangan eksposisi dengan aplikasi media gambar pada peserta didik keIas VIII di SMP Negeri 24 Banjarmasin. 


\section{Metode Penelitian}

\section{Jenis Penelitian}

Jenis dari penelitian ini merupakan penelitian kualitatif yang bersifat deskriptif. Penelitian dengan metode deskriptif merupakan metode penelitian yang berfungsi memaparkan data dengan natural dan tanpa perubahan.

\section{Waktu dan Tempat Penelitian}

Penelitian ini dilakukan pada tanggal 6 hingga 9 Februari 2019 di kelas VIII A SMP Negeri 24 Banjarmasin.

\section{Target atau Subjek Penelitian}

Subjek yang terdapat pada penelitian merupakan tenaga pendidik sebagai pengajar serta peserta didik kelas VIII A di SMP Negeri 24 Banjarmasin yang melaksanakan pembelajaran menulis karangan eksposisi meggunakan medi agambar. Guru bidang studi bahasa Indonesia dikelas VIII A SMP Negeri 24 Banjarmasin adalah Relawati, S.Pd., adapun peserta didik yamg berperan pada penelitian ini adalah peserta didik di kelas VIII A.

\section{Prosedur}

Data, Instrumen, dan Teknik

\section{Pengumpulan data}

Data yang terdapat pada penelitian ini yakni proses dan tahapan pelaksanaan pembelajaran menulis karangan eksposisi dengan penggunaan media gambar. Di mana dalam penelitian ini, instrumen kunci merupakan peneliti yang bersifat sebagai human instrumen bertugas memutuskan pokok permasalahan, menetapkan sumberdata, melakukan pendataan, mengolah data, menggambarkan datanya, serta menyimpulkan data (Sugiyono, 2013: 305-306).

Tehnik yang dipakai dalam proses pengumpulan data dapat dipaparkan berikut ini.

1. Observasi (pengamatan)

Observasi adalah proses keterlibatan peneliti dalam melakukan pengamatan pada proses pembelajaran yang dilakukan guru sebagai pengajar dengan peserta didik di kelas. Adapun komponen belajarmengajar yang diamati merupaka materi pembelajaran menulis karangan eksposisi menggunakan media gambar.

2. Wawancara

Wawancara dilakukan untuk mencari informasi secara lebih mendalam kepada oknum-oknum yang terkait pada proses pengambilan data. Pada penelitian ini, wawancara yanng dipraktikkan adalah jenis wawancara yang tidak terikat 
pedoman. Oleh karena itu, pertanyaan-pertanyaan yang diungkap oleh peneliti hanya berupa garis besar dari permasalahan (Sugiyono, 2013: 312). Pada penelitian ini, penulis melaksanakan wawancara seraya mengajukan pertanyaanpertanyaan secara lisan kepada pengajar di bidang studi bahasa Indonesia kelas VIII A di SMP Negeri 24 Banjarmasin, yaitu Relawati, S.Pd..

3. Dokumentasi

Dokumentasi menurut Sugiyono (2013: 240) adalah tulisan dari kejadian atau peristiwa yang sudah dilaksanakan. Teknik dokumentasi yang digunakan pada penelitian ini adalah dengan perekaman pada prosesi pelaksanaan pembelajaran menulis karangan eksposisi dengan penggunaan media gambar. Bentuk dokumentasi lainnya adalah Rancangan Pelaksanaan Pembelajaran (RPP) yang digunakan oleh guru sebagai pengajar, serta foto-foto dokumentasi peristiwa atau kegiatan proses pembelajaran.

\section{Teknik Analisis Data}

Aktivitas atau kegiatan dalam proses teknik analisis data adalah mereduksi data (data reduction), menyajikan data (datadisplay), dan memverifikasi data (conclusion drawing or verification) (Miles \& Huberman (dalam Sugiyono, 2013)).

1. Reduksi Data (Data Reduction) Mereduksi artinya adalah merangkum, peneliti hanya memilih pembahasan yang utama, mengutamakan data-data yang penting, dan membuang data yang memang tidak diperlukan. Pada penelitian ini, data yang di reduksi adalah bentuk rekaman pada saat pembelajaran proses menulis karangan eksposisi menggunakan media gambar berlangsung. Data yang didapatkan dari hasil rekaman tersebut di reduksi, kemudian dikelompokkan dan di fokuskan agar menjawab pertanyaan mengenai bagaimana proses pelaksanaan pem belajaran menulis karangan eksposisi menggunakan media yang berupa gambar-gambar.

2. Penyajian Data (Data Display)

Tahap ini dibuat daIam format uraian singkat berikut kaitan antara beberapa kategori. 
Menurut pendapat ahli, Miles \& Huberman (dalam Sugiyono, 2013) menyatakan bahwa teks yang bersifat naratif adalah jenis yang paling sering dipakai untuk memaparkan data dalam penelitian kualitatif. Data yang di sajikan pada penelitian ini yakni pemaparan tentang aktivitas antara guru \& peserta didik saat proses pelaksaanan pembelajaran menulis karangan eksposisi menggunakan media gambar sedang berlangsung.

3. Memverifikasi data atau mengkonklusi (Drawing or Verification)

Langkah terakhir yang dilakukan dalam teknik analisis data adalah penarikan simpulan serta verifikasi. Berdasarkan penyajian data yang bersifat naratif, penulis menarik simpulan secara garis besar guna menjawab rumusan masalah mengenai proses pelaksanaan pembelejaran menulis karanga eksposisi mengginakan media gambar.

\section{Hasil Penelitian dan Pembahasan}

Pelaksanaan pembelajaran menulis karangan eksposisi dengan penggunaan media gambar di kelas VIII A dilaksanakan pada tanggal 8 Februari 2019. Proses pembelajaran di laksanakan sesuai dengan Rencana Pelaksanaan Pembelajaran (RPP) yang dirancang langsung oleh guru pengajar Bahasa Indonesia. Metode pembelajaran yang digunakan adalah diskusi, tanya-jawab, dan penugasan. Adapun discovery Iearning merupakan model pembelajaran yang dipilih guru untuk diaplikasikan saat itu.

Proses pelaksanaan pembelajaran menulis karangan eksposisi dengan penggunaan media gambar di kelas VIII A terdiri dari tiga macam kegiatan, di antaranya (1) pendahuluan, berisi salam dan doa, menyiapkan fisik dan psikis peserta didik, serta memberikan motivasi; (2) inti, yang terdiri dari kegiatan $5 \mathrm{M}$, yaitu mengamati, menanya, mengumpulkan informasi, menalar informasi dan mengomunikasikan hasil; serta (3) penutup yang berisi kegiatan menyimpulkan pembelajaran dan pemberian umpan balik. Ketiga kegiatan tersebut dapat di paparkan secara lebih rinci sebagai berikut.

1. Pendahuluan

Kegiatan pertama adalah pendahuluan yang bersifat sebagai awalan atau permulaan pada proses belajar-mengajar. Tahap ini 
bertujuan untuk meningkatkan gairah peserta didik dalam belajar serta mendorong agar mereka aktif pada prosesi pembeIajaran. Pada langkah inilah pembelajaran dimulai dengan orientasi. Guru mengecek kehadiran seluruh siswa dan siswi, kemudian menyiapkan fisikk peserta didik dan juga psikisnya. Proses selanjutnya adalah apersepsi yang berisi kegiatan mengaitkan materi pembelajaran menulis eksposisi dengan materi sebelumnya, yaitu materi struktur dari teks eksposisi yang terdiri atas tesis, rangkaian argumen, dan penegasan ulang. Motivasi menjadi tahap berikutnya pada kegiatan pendahuluan dimana tahap tersebut berisi penjelasan mengenai tujuan pembelajaran yang ingin di capai.

2. Kegiatan Inti

Kegiatan inti merupakan proses pembelajaran yang di laksanakan secara interaktif dan bersifat me motivassi agar Kompetensi Dasar dan tujuan pembelajaran dapat tercapai dan berjalan sesuai dengan Rancangan Pelaksanaan Pembelajaran (RPP). Pada kegiatan ini, guru dan peserta didik menerapkan rangkaian kegiatan yang sesuai dengan pendekatan saintifik. Rangkaian kegiatan tersebut disebut sebagai $5 \mathrm{M}$ yang dipaparkan sebagai berikut.

a) Mengamati

Mufiqon dan Nurdyansyah (2015: 38) menjelaskan bahwa kegiatan mengamati dapat berupa mem baca, menyimak, dan melihat. Sesuai dengan tahap obsevasi peneliti, pada kegiatan ini, peserta didik mengamati langkah-langkah mneyajikan karangan eksposisi yang terdapat pada buku ajar.

b) Menanya

Mufiqon dan Nurdyansyah (2015: 38) memaparkan bahwa kegiatan menanya merupakan proses di mana peserta didik mengajukan pertanyaan yang ber kaitan dengan materi yang telah diamati pesserta didik. Merujuk pada obsevasi yang dilakukan oleh peneliti, pada kegiatan ini, tidak terdapat peserta didik yang mengajukan pertanyaan. Meskipun guru telah berusaha untuk merangsang peserta didik untuk bertanya, namun peserta didik memberikan respon yang pasif. Dengan kata lain, proses menanya tidak terlaksana dengan baik, hal ini disebabkan 
oleh peserta didik yang tidak aktif pada proses menanya. Guru menjelaskan bahwa hal tersebut biasa terjadi sebab peserta didik merasa sungkan dan kurang percaya diri untuk bertanya.

c) Mengumpulkan Informasi

Mufiqon dan Nurdyansyah (2015: 38) mendeskripsikan bahwa mengumpulkan informasi dapat diisi dengan kegiatan mencari-cari beragam informasi atau mengamati suatu objek. Merujuk pada obsevasi yang di lakukan oleh peneliti, pada kegiatan ini, guru menampilkan media gambar sebagai acuan dalam menulis karangan eksposisi. Guru mengarahkan seluruh siswa didik supaya mencari

informasi dari sumber yang beragam yang memiliki kaitan dengan gambar yang ditampilkan di depan kelas. Guru menampilkan gambar dengan tema kebersihan kelas. Media gambar tersebut antara lain (1) kelas yang bersih dan rapi; (2) sampah yang berserakan di lingkungan sekolah; (3) kegiatan membersihkan kelas; (4) piagam penghargaan lomba kebersihan kelas; dan (5) suasana belajar mmengajar yang nyaman.

d) Mengasosiasi atau Mengolah Infomasi

Mufiqon dan Nurdyansyah (2015: 38) menjelaskan bahwa bentuk kegiatan pada tahap ini adalah pengolahan informasi yang sifatnya menambah khazanah wawasan hingga informasi yang saling mendukung materi pembelajaran menulis karangan eksposisi. Merujuk pada obsevasi yang dilakukan oleh peneliti, pada langkah inilah pengajar memancing siswa didik agar mereka mendiskusikan informasi yang didapatkan secara bersamasama di kelas. Adapun setelah proses diskusi dilaksanakan, peserta didik menulis dan mendokumnetasikan materimateri pokok yang memiliki hubungan dengan tema dan isi karangan serta mulai merancang karangan eksposisinya masing-masing.

e) Mengomunikasikan

Mufiqon dan Nurdyansyah (2015: 38) berpendapat bahwa 
kegiatan mengomunikasikan merupakan penyampaian hasil kerja peserta didika yang di lakukan baik secara lisan maupun tertulis. Merujuk pada obsevasi yang dilakukan oleh peneliti, peserta didik diberi waktu selama 40 menit untuk mengembangkan karangan eksposisi berdasarkan media gambar yang ditunjukkan di depan kelas. Selama proses menulis karangan tersebut, peserta didik sering kali memerhatikan kembali media gambar yang ditampilkan di papan tulis. Selain itu, peserta didik pun seringkali ber tanya mengenai tema dan isi tulisannya kepada guru selama proses menulis berlangsung.

Setelah peserta didik selesai menulis karangan eksposisi, peserta didik mempresentasikan hasil karangannya dan ditanggapi oleh peserta didik lainnya. Pada momen ini lah guru bertugas menilai dan meluruskan diskusi yang dilakukan peserta didik agar tetap terarah sesuai dengan tema yang dipilih.

3. Kegiatan Penutup
Kegiatan penutup merupakan kegiatan yang dilaksanakan untuk mengnutup dan mengakhiri proses pembelajaran. Guru sebagai pengajar mengakhiri pembelajaran dengan mengajak peserta didik menyimpulkan pembelajaran secara bersama-sama. Tahap terakhir adalah peserta didik mendapat umpan balik dari guru dengan cara guru memuji kinerja yang telah di lakukan oleh peserta didik. Selain itu, guru juga berusaha mendorong semangat peserta didik untuk lebih aktif lagi dalam proses pembelajaran berikutnya .

\section{Simpulan dan Saran}

\section{Simpulan}

Berikut ini merupakan proses pelaksanaaan pembelajaran menuliis karangan eksposisi menggunakan media bergambar di kelas VIII A SMP Negeri 24 Banjarmasin yang dilaksanakan pada 8 Februari 2019.

1. Pendahuluan, berisi pembuka serta doa, guru sebagai pengajar mengecek kehadiran, guru menyiapkan fisik \& psikis anak, guru beserta peserta didik mengaitkan materi ajar dengan pembelajaran sebelumnya, guru 
memberikan pertanyaaan

berhubungan dengan

pembelajaran yang

dilaksanakan, guru menjelaskan

tujuan dan manfaat

pembelajaran, serta guru

menjelaskan secara singkat

materi yang akan dibahas.

Secara umum, kegiatan ini

telah berjalan dengan baik.

2. Inti, terdiri atas kegiatan $5 \mathrm{M}$, yaitu mengamati, menaya, mengumpulkan info, menalar dan mengomunikasian hasil. Di tahap ini, kegiatan belajarmengajar telah dilaksanakan sesuai dengan rancangan kegiatan. Akan tetapi, pada kegiatan menanya masih belum terlaksana sesuai rencana, sebab peserta didik masih pasif pada saat pembelajaran berlangsung.

3. Penutup, terdiri atas kegiatan menyimpulkan mengenai pembelajaran, peserta didik menerima umpan balik oleh guru, guru memberikan tugas pengayaan, serta peserta didik berdoa dan memberi salam. Secara umum, kegiatan ini telah terlaksana dengan baik sesuai rencana yang telah di susun pengajar.

\section{Saran}

1. Peserta didik sebaiknya memelajari materi yang akan diajarkan terlebih dahulu agar peserta didik dapat lebih kritis pada saat proses pembelajaran.

2. Guru sebaiknya membagikan motivasi dan penguatan kepada peserta didik agar lebih bersemangat pada prosses pembelajaran.

3. Sebaiknya pejabat sekolah melengkapi kelas dengan sarana dan pra sarana yang lebih menunjang agar prosesi belajar-mengajar menjadi lebih menarik.

4. Peneliti selanjutnya sebaiknya merancang penelitian yang lebih mendalam mengenai peng gunaan media gambar dan juga manfaatnya bagi dunia pendidikan.

\section{Daftar Pustaka}

Abidin, Yunus. (2012). Permbelajaran Menulis dalam Gamitan Pendidikan Karakter. Bandung: Universitas Pendidikan Indonesia.

Arikunto, Suharsimi. (2010). Prosedur Penelitian Suatu Pendekatan Praktik. Yogyakarta: Rineka Cipta.

Dewi, Andi Susi Suriana Puspita. (2016). Kemampuan Menulis Paragraf Eksposisi Peserta didik Kelas X SMA Negeri 12 Konawe Selatan. Jurnal Humanika No. 16 Vol. 1, halaman 2-3.

Fitriyani, Epri, dkk.. (2014). Pembelajaran Struktur Teks Eksposisi pada Siswa 
Kelas VII SMPN 1 Bandarlampung, Jurnal Kata (Bahasa, Sastra, dan Pembelajarannya), halaman 2.

Kementerian Pendidikan dan Kebudayaan Jakarta. (2017). Model Siilabus Mata Pelajaran Sekolah Menengah Pertama/Madrasah Tsanawiyah (SMP/MTS) Mata Pelajaran Bahasa Indonesia. Jakarta: Kementerian Pendidikan dan Kebudayaan.

Kementerian Pendidikan dan Kebudayaan Republik Indonesia. (2017). Bahasa Indonesia SMP/MTs Kelas VIII. Jakarta: Kementerian Pendidikan dan Kebudayaan.

Kementerian Pendidikan dan Kebudayaan. (2016). Peraturan Menteri Pendidikan dan Kebudayaan Nomor 22 Tahun 2016 tentang Standar Proses Pendidikan Dasar dan Menengah. Jakarta: Kementerian Pendidikan dan Kebudayaan.

Musaba, Zulkifli dan Moh. Siddik. (2017). Dasar-Dasar Keterampilan Menulis. Yogyakarta: Aswaja Pressindo.

Nursisto. (1999). Penuntun Mengarang. Jakarta: Aditia Karya Nusa.

Putri, Dainur. (2012). Krmampuan Menulis Karangan Persuasi Peserta didik Kelas X SMAN 1 Kabupaten Solok Selatan. Jurnal Al-Ta'lim, Jilid $I$, .

Putri, Sella Destriani. (2016). Pembelajaran Menulis Teks Eksposisi pada Kelas VII MTs Negeri 1 Bandar Lampung Tahun Pelajaran 2015/2016. Jurnal .

Rahmawati, Aulia, dkk. (2013). Pelaksanaan Pem belajaran Menulis Teks Negosiasi pada Siswa SMA Kemala Bhayangkari Kabupaten Kubu Raya. Jurnal

Rofi'uddin, Ahmad dan Darmiyati Zuhdi. (1999). Pendidikan Bahasa dan
Sastra Indonesia di Kelas Tinggi. Jakarta: Depdikbud.

Sugiyono. (2013). Metode Penelitian Pendidikan Pendekatan Kuantitatif, Kualitatif, dan $R \& D$. Bandung: Alfabeta.

Suriamiharja. (1997). Petunjuk Praktik Me nulis. Jakarta: Depdikbud.

Tarigan, Henry Guntur. (2008). Menuliss sebagai Suatu Keterampilan Berbahasa. Bandung: Angkasa. 